\title{
Tranilast, an analogue of tryptophan catabolites, induces allograft tolerance by $\mathrm{CD} 161^{+}$cells
}

\author{
Séverine Ménoret ${ }^{1 *}$, Séverine Bézie ${ }^{2}$, Xian-Liang Li ${ }^{2}$, Claire Usal $^{2}$, Lise Caron ${ }^{2}$, Ignacio Anegon ${ }^{2}$ \\ From 6th European Workshop on Immune-Mediated Inflammatory Diseases \\ Nice, France. 23-25 November 2011
}

\section{Background}

Indoleamine 2, 3-dioxygenase (IDO) converts tryptophan in various catabolites and has been shown to induce immune tolerance in different immune-mediated diseases, including organ transplantation. One of these tolerogenic metabolites is anthranilic acid. Tranilast is a clinically approved, structural and functional analogue of anthranilic acid that has been recently shown to be effective in murine models of multiple sclerosis and rheumatoid arthritis. We examined the effect of tranilast in a rat cardiac allograft model.

\section{Materials and methods}

Lewis $1 \mathrm{~W}$ rat hearts were grafted in MHC-mismatched Lewis $1 \mathrm{~A}$ rats. The receiver is orally treated with $650 \mathrm{mg} / \mathrm{kg}$ of tranilast daily for 30 days. Total splenocytes and purified spleen cell subtypes sorted by FACS Aria were transferred to sublethaly irradiated rats by $i . v$ injection the day before transplantation.

\section{Results}

Graft survival in recipients treated with tranilast were significantly prolonged $(66.3 \pm 46.7$ days, $\mathrm{n}=53, \mathrm{p}<0,0001)$ when compared to control group $(8.3 \pm 2.3$ days, $n=6)$ and in $45 \%$ of recipients $(n=53)$ tranilast induced tolerance ( $>100$ days survival). Adoptive transfer of total splenocytes from tolerant tranilast-treated rats to naïve rats resulted in tolerance in all animals $(n=5)$. Moreover, splenocytes from these adoptively transferred tolerant recipients were again capable of transferring tolerance to all naïve recipients $(n=5)$. Tolerant splenocytes depleted of $T$ and B cells $(n=6)$ or depleted of T, B and DCs $(n=5)$ transferred tolerance. Importantly, depletion of CD161 ${ }^{+}$ cells from T, B and DCs-depleted splenocytes abrogated tolerance transfer $(9.3 \pm 0.6 \mathrm{n}=3)$. To confirm these

${ }^{1}$ Plateform Transgenic Rats Nantes IBiSA-CNRS, Nantes, France Full list of author information is available at the end of the article results, we adoptively transferred $\mathrm{CD} 161^{+} \mathrm{TCR}^{-}$cells from tolerant rats which resulted in tolerance $(130 \pm 91.6$ days, $\mathrm{n}=5,3 / 5$ recipients $>100$ days) whereas $\mathrm{CD} 161^{-} \mathrm{TCR}^{-}$cells from the same animals did not $(12.7 \pm 4.6$ days, $n=3$, $\mathrm{p}<0,005)$.

\section{Discussion}

This is the first demonstration that tranilast mediates transplantation tolerance. Tolerance was active and transferable by CD161+TCR- cells that comprise NK cells $\left(\mathrm{CD} 161^{\text {high }}\right)$ and myeloid-derived suppressor cells $\left(\mathrm{CD} 161^{\mathrm{low}}\right)$. Experiments are under way to define which of these cell populations mediate tranilast-induced tolerance and by which downstream mechanisms.

\section{Author details}

'Plateform Transgenic Rats Nantes IBiSA-CNRS, Nantes, France. ${ }^{2}$ INSERM UMR 643, Nantes, France.

Published: 23 November 2011

doi:10.1186/1479-5876-9-S2-P27

Cite this article as: Ménoret et al:: Tranilast, an analogue of tryptophan catabolites, induces allograft tolerance by $\mathrm{CD} 161^{+}$cells. Journal of Translational Medicine 2011 9(Suppl 2):P27.

Submit your next manuscript to BioMed Central and take full advantage of:

- Convenient online submission

- Thorough peer review

- No space constraints or color figure charges

- Immediate publication on acceptance

- Inclusion in PubMed, CAS, Scopus and Google Scholar

- Research which is freely available for redistribution 